\title{
Insights into the Mechanism of Action and Cellular Targets of Ruthenium Complexes from NMR Spectroscopy
}

\author{
Federico Giannini, Lydia E. H. Paul, and Julien Furrer ${ }^{\star}$
}

\begin{abstract}
NMR spectroscopy has proved extremely beneficial in the investigation of inorganic drugs from the time that cisplatin was first introduced into the clinic more than 30 years ago. Both ${ }^{195} \mathrm{Pt}$ and ${ }^{15} \mathrm{~N} \mathrm{NMR}$ were used in early studies and made a major contribution in the understanding of the molecular mechanism of action from model studies involving reactions with amino acids and nucleotides. Over the past decade, ruthenium drugs have proved to be a valuable alternative to platinum drugs, and NMR has also provided unique insights into their molecular mechanism of action including investigations of simple aquation reactions, protein binding and the kinetics and sequence selectivity of DNA binding interactions. In this article, emphasis is given to define the cellular targets and elucidate some of the mechanistic profiles of recent ruthenium-based organometallic compounds offering efficacy toward cancer cells, by various NMR techniques.
\end{abstract}

Keywords: Cellular targets · Cytotoxicity · Glutathione oxidation · NMR spectroscopy $\cdot$ Ruthenium complexes

\section{Introduction}

Nowadays, anticancer platinum complexes (Fig. 1) are still the unique metallodrugs used in cancer chemotherapy, mainly because of the massive research effort that followed the opportune discovery of the anticancer properties of cisplatin in the late 1960s. ${ }^{[1]}$ One of the most impressive examples of the cisplatin impact is the case of testicular cancer. Prior to the introduction of cisplatin in the clinic about $90 \%$ of patients with testicular cancer died of the disease, and following its application this percentage was reversed with $90 \%$ of cases cured. [2] In spite of numerous drawbacks, such as severe toxicity (nephrotoxicity), drug resistance, or poor oral bioavailability, the application of cisplatin has revolutionized anticancer clinical practices to such an extent that it is still used nowadays, albeit mostly in combination with other organic drugs. The limitations of cisplatin have led to a massive investigation into the cytotoxicity and genotoxicity of platinum compounds, including the study of the interactions of various platinum complexes with nucleotides, nucleic acids, carbohydrates, proteins and cells, in order to elucidate their molecular mechanisms and identify key biomolecular targets for rational drug design. ${ }^{[3-6]}$ From this tremendous amount of research, two compounds, carboplatin and oxaliplatin, are currently used worldwide, and have demonstrated milder side effects compared to the parent drug. [7] There are other platinum drugs, such as Nedaplatin, Lobaplatin, and Heptaplatin, used in cancer chemotherapy, but they are currently restricted to certain areas or countries. ${ }^{[7]}$

Ruthenium complexes have been known for a long time to possess anticancer properties, ${ }^{[8,9]}$ but it was shown only recently that these compounds have several advantages compared to the platinum drugs. [10-12] Ruthenium complexes are generally more selective towards cancer cells and therefore show fewer side effects than cisplatin. [13] Nowadays two inorganic ruthenium-based drugs have already completed phase I clinical trials, namely NAMI-A[14] and KP1019[15] (Fig. 2). NAMI-A has already started and KP1019 will soon start phase II clinical trials. ${ }^{[14-16]}$ These two compounds possess similar structural features but show very different activity towards cancerous tissue. NAMI-A is most effective against lung metastases while KP1019 is used to treat colon carcinomas. Other ruthenium complexes are also very promising, for instance the RAPTA family, ${ }^{[17]}$ ONCO4417, [18,19] and DW $1 \& 2^{[20,21]}$ (Fig. 2).

Interestingly, NAMI-A, KP1019 and the RAPTA complexes only induce weak in vitro cytotoxicity, show only modest and reversible DNA adduct formation, but have promising clinical applications leading to apoptosis activation rather than primary tumor inhibition. ${ }^{[4,22]}$ Nevertheless, after more than 15 years the exact target(s) of KP1019 and of NAMI-A remain unidentified, which points out the difficulties to study this aspect. The lack of information on the target(s) undoubtedly hampers the possibility to explore new analogues of KP1019 or of NAMI-A with superior pharmacological profiles. The more recent RAPTA compounds have a markedly different general chemistry to NAMI-A. ${ }^{[23]}$ It was recently found that RAPTA compounds have a strong preference for protein binding over DNA, as shown from the ca. $200 \mathrm{kDa}$ crystal structure of the nucleo-

\footnotetext{
${ }^{\star}$ Correspondence: Dr. J. Furrer

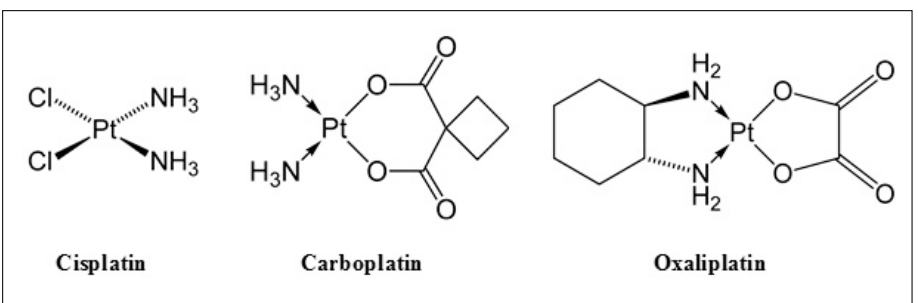

Fig. 1. The current three platinum-based anticancer drugs which have gained marketing approval for human use worldwide. 

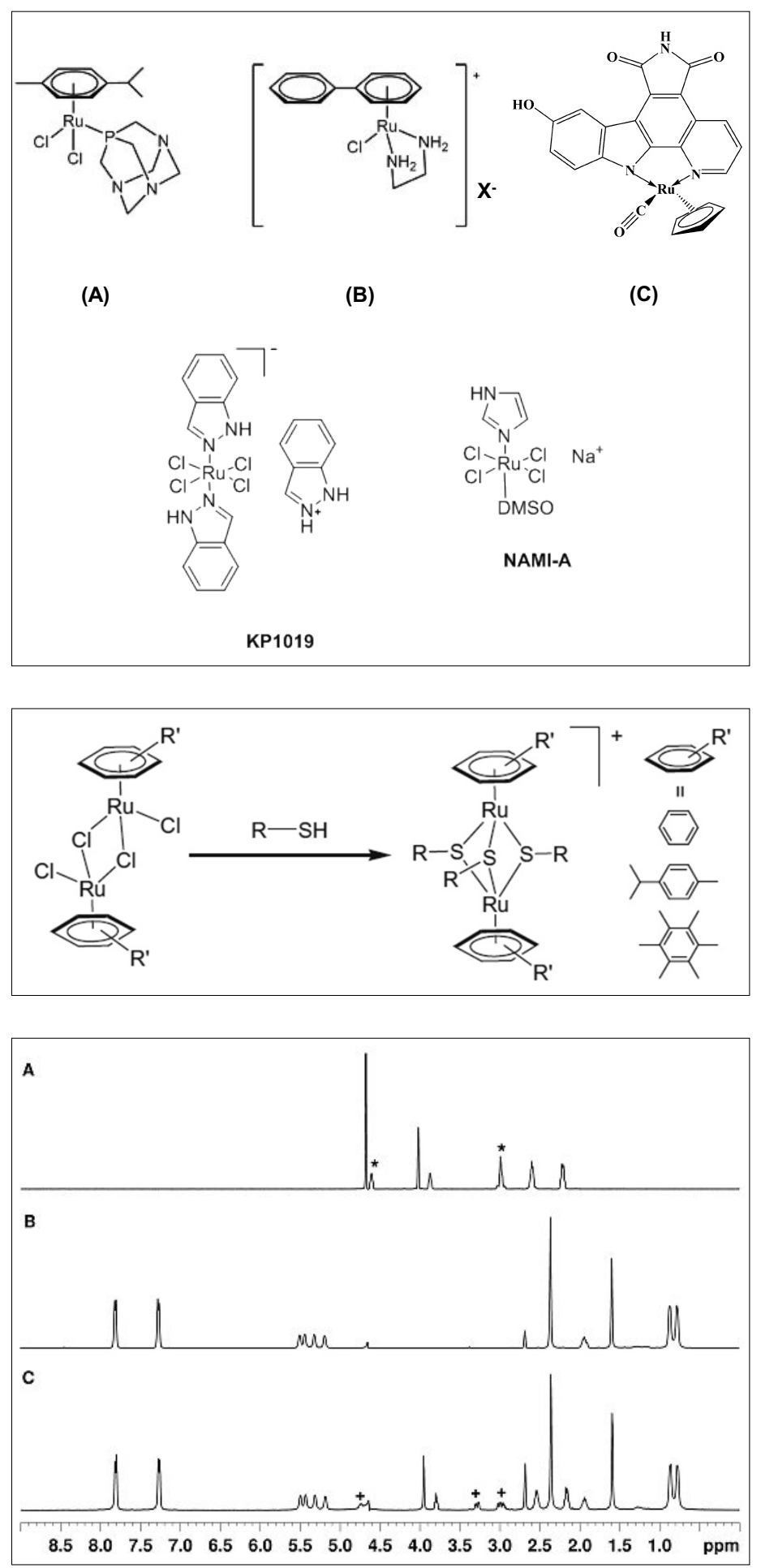

Fig. 3. ${ }^{1} \mathrm{H}$ NMR spectra of glutathione (GSH) (A),

$\left[\left(\eta^{6}-p-\mathrm{MeC}_{6} \mathrm{H}_{4} \mathrm{Pr}\right)_{2} \mathrm{Ru}_{2}\right.$ $\left.\left(\mathrm{SC}_{6} \mathrm{H}_{4}-p-\mathrm{CH}_{3}\right)_{3}\right] \mathrm{Cl}(\mathrm{B})$, and of the mixture $\left[\left(\eta^{6}-p-\mathrm{MeC}_{6} \mathrm{H}_{4} \mathrm{Pr}\right)_{2} \mathrm{Ru}_{2}\right.$ $\left.\left(\mathrm{SC}_{6} \mathrm{H}_{4}-p-\mathrm{CH}_{3}\right)_{3}\right] \mathrm{Cl}$ : GSH (ratio 1:1), (C) recorded at $37^{\circ} \mathrm{C}$ in $\mathrm{D}_{2} \mathrm{O} / \mathrm{DMSO}^{-\mathrm{d}_{6}}(\mathrm{95:5})$ after 2 hours incubation. The resonances of cysteine (GSH) are indicated by * and the resonances of cystine (GSSG) by ${ }^{+}$.

some core particle in which RAPTA-C binds only to the protein histone core. ${ }^{[24]}$

Furthermore, the mode of action, uptake and the biological processes in these systems remain poorly or only partly understood. ${ }^{[25]}$ NMR spectroscopy is a candidate of choice to answer these questions, since one- and two-dimensional NMR spectroscopy of metal complexes have proven to be extremely powerful in elucidating interactions between complexes with potential anticancer activity and biomolecules. ${ }^{[26-28]}$ Indeed, very interesting reports and promising results revealing interactions between metal complexes and biomol- ecules using NMR spectroscopy have been published in the last few years. [29-32] However, the binding properties of ruthenium complexes with biomolecules using NMR studies seem to be a relatively unexplored domain, as revealed by the few publications on this subject.

In recent years, we as well as others have developed a series of rutheniumbased organometallic compounds offering efficacy toward cancer cells. ${ }^{[33-47]}$ The aim of our research is to define cellular targets of the compounds and elucidate some of their mechanistic profiles by various NMR techniques.

\section{Highly Cytotoxic Trithiophenolato Diruthenium Complexes}

In a very interesting perspective review, Gianferra et al. have suggested a categorization of metal anticancer compounds into five classes based on their mode of action: i) functional compounds, like cisplatin, NAMI-A or KP1019, in which the metal has a functional role, i.e. it binds to the biological target; ii) structural compounds, in which the metal only has a structural role, i.e. it determines the global shape of the compound. The binding to the biological target occurs only through non-covalent interactions; iii) carrier compounds, in which the metal acts as a carrier for active ligands that are expected to be delivered in vivo; iv) catalytic compounds, in which the metal compound acts as a catalyst; and v) photoactive compounds, in which the metal compound is photoactive and behaves as a photo-sensitizer (porphyrins, PDT therapy). [48]

Recently, we have synthesized and characterized ruthenium complexes with the general formula $\left[\left(\eta^{6}-\right.\right.$ $\left.\left.p \mathrm{CH}_{3} \mathrm{C}_{6} \mathrm{H}_{4} \mathrm{Pr}^{i}\right)_{2} \mathrm{Ru}_{2}\left(\mathrm{SC}_{6} \mathrm{H}_{4}-p-\mathrm{X}\right)_{3}\right]^{+}($Scheme 1). $[49,50]$ The stability and reactivity of these complexes towards biomolecules were assessed by recording various NMR spectra. ${ }^{51]}$ Surprisingly, only Cys and GSH (native glutathione) induced changes in the ${ }^{1} \mathrm{H}$ and ${ }^{13} \mathrm{C}$ NMR spectra compared to the free components. Fig. 3 shows the ${ }^{1} \mathrm{H}$ NMR spectra obtained upon titration of GSH into a solution of the complex 1 with $\mathrm{X}=\mathrm{CH}_{3}$ in $\mathrm{D}_{2} \mathrm{O}$ with $50 \mathrm{mM} \mathrm{NaCl}$. As can be seen in the ${ }^{1} \mathrm{H}$ NMR spectrum of free GSH, the addition of 1 equivalent of GSH resulted in the appearance of new Cys resonances at $\delta$ $4.78(\mathrm{H} \alpha), 3.33\left(\mathrm{H} \beta^{\prime}\right)$, and $3.04 \mathrm{ppm}(\mathrm{H} \beta)$, which increased over time relative to the signals of free GSH and were assigned as arising from oxidized glutathione (GSSG). Likewise, addition of $\mathbf{1}$ equivalent of Cys resulted in the appearance of new Cys resonances at $\delta 4.17(\mathrm{H} \alpha), 3.46\left(\mathrm{H}^{\prime}\right)$, and $3.27 \mathrm{ppm}(\mathrm{H} \beta)$. These new ${ }^{1} \mathrm{H}$ signals also increased over time, relative to the signals of free Cys, and, in agreement with the literature, were assigned as arising from cystine, the oxidized form of cysteine. ${ }^{[52]}$

Interestingly, these titration experiments with Cys and GSH revealed that only the ${ }^{1} \mathrm{H}$ and ${ }^{13} \mathrm{C}$ chemical shifts of the $\alpha-\mathrm{CH}$ and $\beta-\mathrm{CH}_{2}$ groups of $\mathrm{Cys}$ were affected, whereas the chemical shifts of the complex and the other amino acids of GSH ( $\gamma$-Glu and Gly) remained unperturbed (Fig. 3). These results strongly suggest that Cys and GSH do not form stable adducts with the complexes, which was further evidenced by DOSY spectra (Fig. 4). From these NMR experiments, it became apparent that these complexes could act as a very efficient catalyst for oxidation 
of Cys to cystine and of GSH to GSSG (Scheme 2).

In the light of our studies on these dinuclear arene ruthenium trithiolato complexes, it appears that they belong to class (iv), catalytic compounds. Indeed, we have shown by NMR that they remain intact for long periods, and are inert upon the addition of glucose, all natural amino acids and nucleotides. This category encompasses a recently discovered mode of action found for areneruthenium iodoazopyridine complexes, which are surprisingly cytotoxic despite their inertness to ligand substitution: In a pioneering study, Sadler and coworkers demonstrated these complexes to act as catalysts for oxidation of the tripeptide glutathione, supposed to be at the origin of their anticancer activity. ${ }^{53]}$ Our results however suggest that the oxidation of GSH to form GSSG is not the unique mechanism of action of these compounds, since we could not correlate the rate of oxidation with the cytotoxicity. ${ }^{[54]}$ Indeed, there is no clear correlation between the $\mathrm{IC}_{50}$ and the $\mathrm{TOF}_{50}$ values. However, the cytotoxicity can be to some extent correlated to physicochemical properties of the compounds determined by the electronic influence of the substituents X (Hammett constants $\sigma_{\mathrm{r}}$ ) and the lipophilicity of the thiols $p$ - $\mathrm{XC}_{6} \mathrm{H}_{4} \mathrm{SH}$ (calculated $\log \mathrm{P}$ parameters). In Fig. 5, a three-dimensional graphical representation of the correlation between $\mathrm{IC}_{50}$ values against A2780 cancer cells, the Hammett constants $\sigma_{\mathrm{p}}$, and the lipophilicity parameters $\log \mathrm{P}$ for the eleven complexes is displayed. Interestingly, the optimization problem admits a unique solution described by a second order polynomial function. The regression shows a good non-linear determination coefficient $R^{2}=0.92$. In this representation, the optimal region encompassing the most favorable values for both the Hammett constants $\sigma_{\mathrm{p}}\left(-0.2<\sigma_{\mathrm{p}}<0\right)$ and $\log \mathrm{P}$ values $(\log \mathrm{P}$ $>3.0$ ) leading to the lowest $\mathrm{IC}_{50}$ values is apparent.

Therefore, we expect that these compounds also belong to class (ii), namely the class of structural compounds, i.e. the global shape of the complexes shall be partly responsible for the binding to the biological targets through non-covalent interactions. Current studies for determining whether these complexes bind to DNA and proteins are under investigation, as a first instance using NMR spectroscopy.

\section{Interaction of Ruthenium Hexacationic Prisms with Biological Ligands}

Since the discovery of the Enhanced Permeability and Retention effect in $1986,{ }^{[55]}$ the design of supramolecular

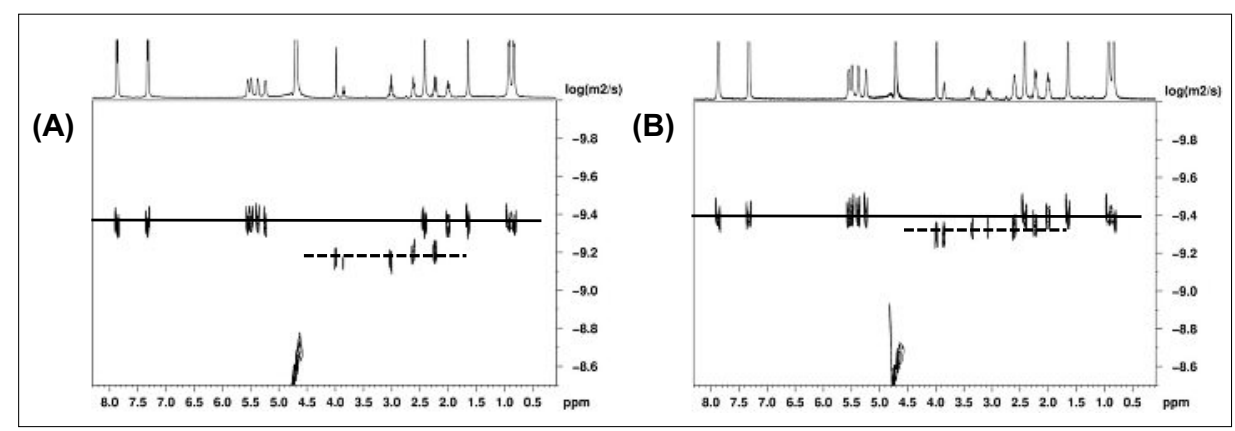

Fig. 4. DOSY spectra of the mixture 1:GSH (ratio 1:1) recorded in $\mathrm{D}_{2} \mathrm{O}$ at $37^{\circ} \mathrm{C}$ after $5 \mathrm{~min}(\mathrm{~A})$, and after $2 \mathrm{~h}$ at $100 \%$ conversion (B). The diffusion coefficient of 1 is indicated with a straight line and the diffusion coefficients of GSH (A) and GSSG (B) are indicated with dashed lines, respectively.

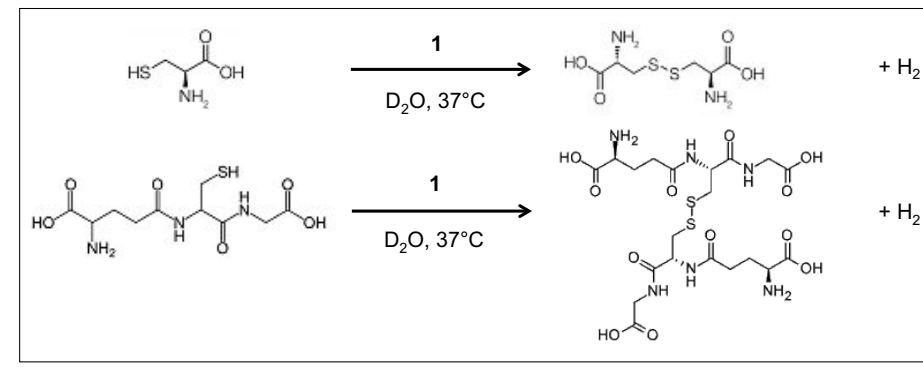

Scheme 2. Oxidation of cysteine (Cys) and glutathione (GSH) to give the disulfide cystine and GSSG, respectively.

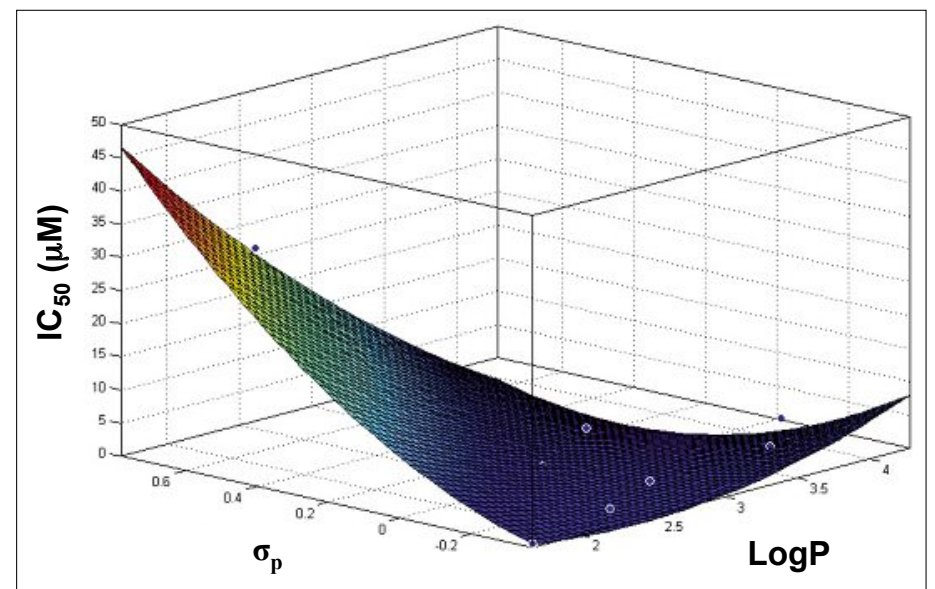

Fig. 5. Threedimensional representation of the correlation between $\mathrm{IC}_{50}$ values against the A2780 cell line, the Hammett constants $\sigma_{\mathrm{p}}$ and the lipophilicity parameters LogP for the eleven ruthenium complexes. Regressions show a non-linear determination coefficient $R^{2}=0.92$.
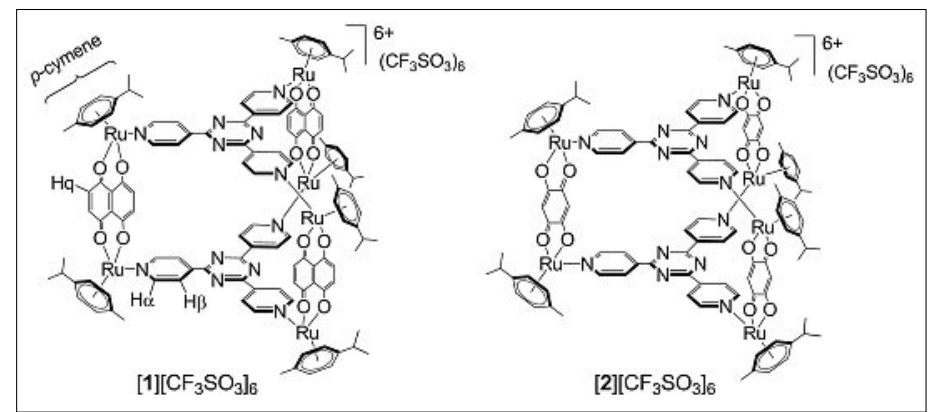

Fig. 6. Hexanuclear metallaprism [1] $\left[\mathrm{CF}_{3} \mathrm{SO}_{3}\right]_{6}$ and [2] $\left[\mathrm{CF}_{3} \mathrm{SO}_{3}\right]_{6}$

assemblies of various sizes and functionalities gained a lot of attention. ${ }^{56,57]}$ The literature shows many different approaches towards combining transition metal ions with different polydentate ligands to produce large metalla assemblies. Our group and colleagues in Neuchâtel have designed hexacationic areneruthenium metallaprisms (Fig. 6) able to encapsulate reversibly inside the cavity planar metal complexes such as $\mathrm{Pt}(\mathrm{acac})_{2}$ or $\mathrm{Pd}(\mathrm{acac})_{2}{ }^{[58]}$ The encapsulated metal complexes remain stable, with the physical properties of the prism being retained following encapsulation. Interestingly, the activity of $[2]^{6+}$ $\left(\mathrm{IC}_{50}=23 \mu \mathrm{M}\right)$ against A2780 cancer cell lines of the metallaprism significantly increases with the encapsulation of $\mathrm{Pt}(\mathrm{acac})_{2}$ or $\mathrm{Pd}(\mathrm{acac})_{2}\left(\mathrm{IC}_{50}=12\right.$ and $1 \mu \mathrm{M}$, respectively) suggesting transport and leaching of the guest once inside the cell. [58]

The metallodrugs currently used in antitumor therapy (cisplatin, carboplatin, oxaliplatin) are administered intravenously 
and can therefore encounter various reactive biomolecules in the bloodstream. The concentration of such biomolecules (ascorbic acid, glucose, lactic acid) is such that they should be considered as primary potential binding partners for metallodrugs. Some proteins like albumin or transferrin play an important in deactivating them even before reaching these targets. ${ }^{[59-61]}$

In recent studies, we have investigated the behavior of two hexacationic areneruthenium metallaprisms $\left[\mathrm{Ru}_{6}(p-\right.$ cymene $\left.)_{6}(\mathrm{dhnq})_{3}(\mathrm{tpt})_{2}\right]^{6+}\left([\mathbf{1}]^{6+}\right)$ and $\left[\mathrm{Ru}_{6}(p-\right.$ cymene $\left.)_{6}(\mathrm{dhbq})_{3}(\mathrm{tpt})_{2}\right]^{6+} \quad\left([2]^{6+}\right)$ against different biological ligands. ${ }^{[62,63]}$ These investigations have been undertaken to clarify the much better cytotoxicity of the prism $[\mathbf{1}]^{6+}\left(\mathrm{IC}_{50}=2 \mu \mathrm{M}\right.$ against $\mathrm{A} 2780$ cancer cells) compared to the prism $[2]^{6+},\left(\mathrm{IC}_{50}=\right.$ $23 \mu \mathrm{M}$ against A2780 cancer cells) and to verify their relative reactivity and stability upon the addition of biological ligands.

Our NMR investigations showed that these prisms behave rather differently than other ruthenium based anticancer complexes. For instance, they showed no interactions with amino acids that are known to form stable complexes with $\mathrm{Ru}$ such as Met ${ }^{[64,65]}$ but strongly reacted with the basic amino acids His, Lys, and Arg. Reactions of ruthenium anticancer complexes with Lys and Arg have been hardly reported. More precisely, our NMR investigations have revealed that coordination to the imidazole nitrogen atom in His or to the basic $\mathrm{NH} / \mathrm{NH}_{2}$ groups in Arg and Lys displaces the dhbq and tpt ligands from the ( $p$-cymene) $\mathrm{Ru}$ units, and subsequent coordination to the amino and carboxylato groups forms stable N,N,O metallacycles (Fig. 7). Interestingly, as determined by NMR spectroscopy, we have found that the binding to amino acids proceeds rather rapidly with $[2]^{6+},{ }^{[62]}$ (Fig. 8) or quite slowly with $[1]^{6+[63]}$ (Fig. 9). In addition, for His, the NMR spectra showed that only about $17 \%$ of His reacts with $[\mathbf{1}]^{6+}$, which is confirmed by the presence of the resonances of both the tpt and dhnq moieties in the NMR spectra, which are otherwise absent when the reaction is complete. ${ }^{[62]}$ Taking into account the much longer reaction time and the incomplete reaction of His, $[\mathbf{1}]^{6+}$ appears much less reactive than the smaller metallaprism [2] ${ }^{6+}$ against amino acids with basic side chain residues. The higher cytotoxicity of $[\mathbf{1}]^{6+}$ compared to $[2]^{6+}$ may appear surprising at first glance, since $[\mathbf{1}]^{6+}$ is apparently more chemically inert compared to $[2]^{6+}$. However, a recent study by Hartinger et al. suggests an inverse correlation between metallodrug-protein interaction and cytotoxicity against tumor cells. [66] Similarly, our recent trithiolato arene ruthenium complexes are highly cytotoxic despite their inertness towards biomolecules such as amino acids and nucleotides. ${ }^{51,54]}$

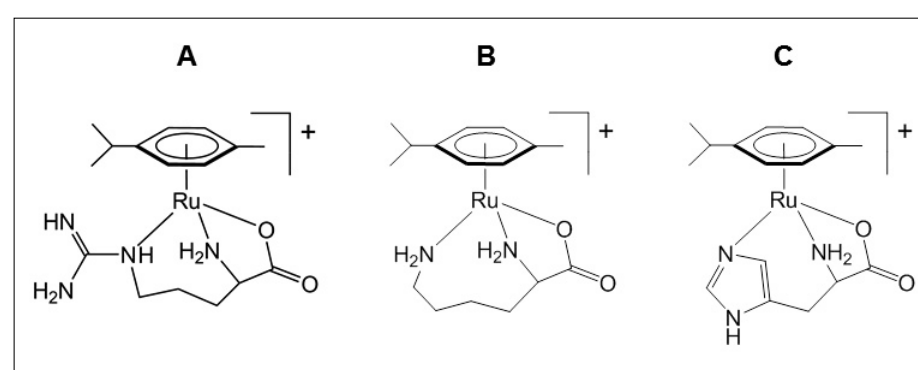

Fig. 7. Suggested (p-cymene)Ru-(AA) chelate complexes obtained upon the addition of $\operatorname{Arg}(A)$, Lys (B), and His (C) to $[1]^{6+}$.

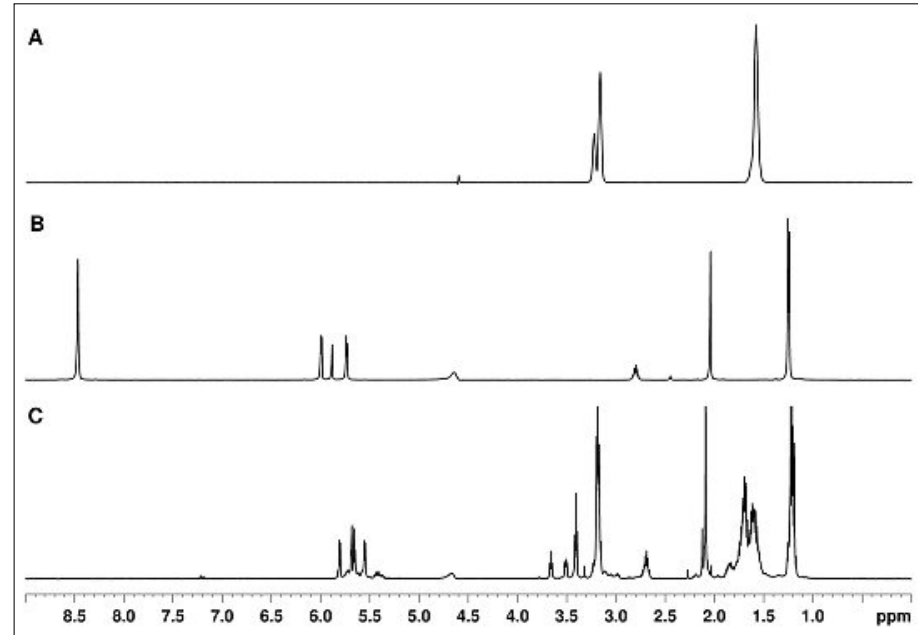

Fig. 8. ${ }^{1} \mathrm{H}$ NMR spectra of $\operatorname{Arg}(A),[1]^{6+}(B)$, and of the mixture $[1]^{6+}:$ Arg (ratio 1:10), recorded after $24 \mathrm{~h}$ (C). All spectra were recorded in $\mathrm{D}_{2} \mathrm{O}$ at $37^{\circ} \mathrm{C}$.

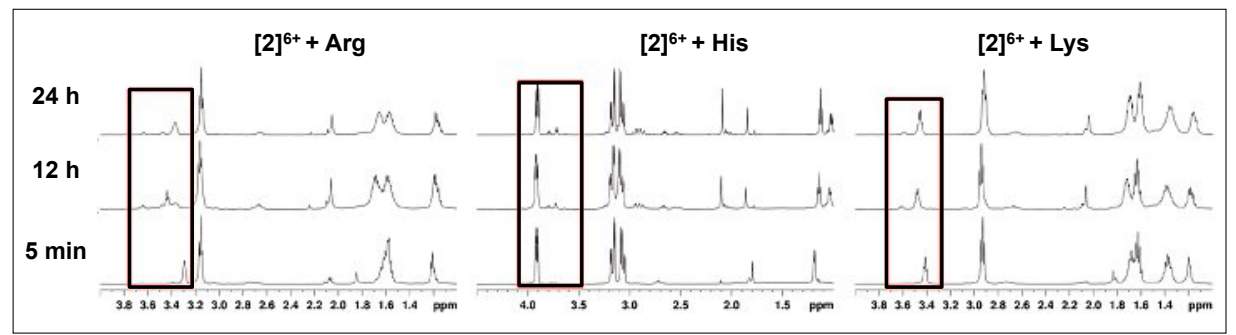

Fig. 9. ${ }^{1} \mathrm{H}$ NMR spectra of the mixture $[2]^{6+}:$ Arg, $[2]^{6+}:$ His, and $[2]^{6+}:$ Lys (ratio 1:10) recorded as a function of the time. Only after $12 \mathrm{~h}$, the occurrence of additional resonances near the original $\mathrm{H} \alpha$ resonances can be clearly observed.

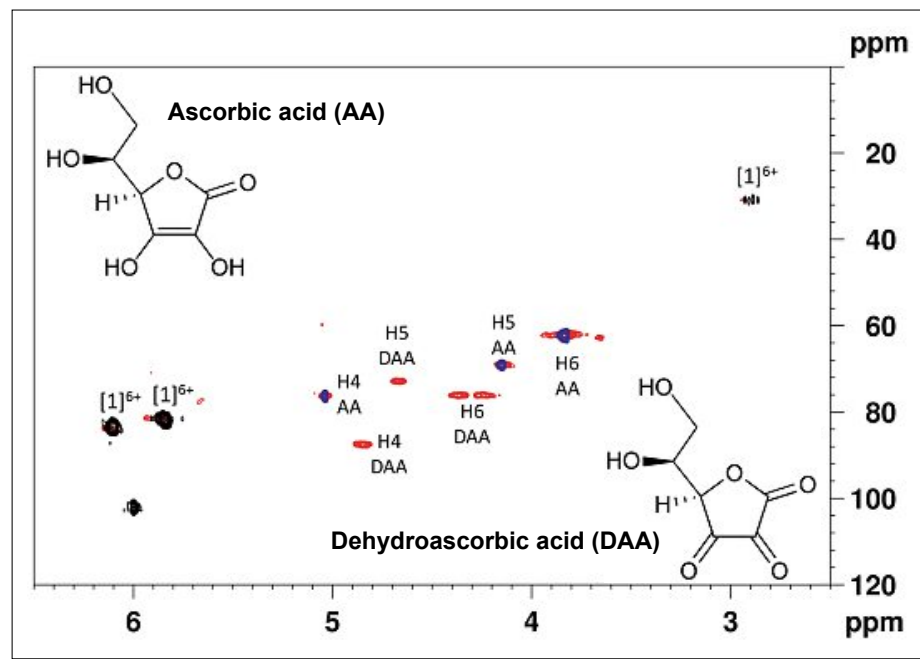

Fig. 10. Excerpt of the $2 \mathrm{D}{ }^{1} \mathrm{H}-{ }^{13} \mathrm{C} \mathrm{HSQC}$ NMR spectrum of the mixture $[1]^{6+}$ :ascorbic acid (ratio 1:6) recorded after $24 \mathrm{~h}$ (red). For comparison, excerpts of the ${ }^{1} \mathrm{H}-{ }^{13} \mathrm{C}$ HSQC NMR spectra of $[1]^{6+}$ (black) and free ascorbic acid (blue) were added.

Moreover, we have found that these metallaprisms are also able to catalyze the oxidation of ascorbic acid, Cys and glutathione (GSH) to form dehydroascorbic acid, cystine and GSSG, respectively ${ }^{[62,63]}$ (Fig. 10). This mode of action involving redox processes and oxidation of GSH, which is supposed to be at least partly at the origin of the observed cytotoxicity of ruthenium complexes, has been rarely reported so far. ${ }^{[51,53]}$ Interestingly, as determined by NMR spectroscopy, we have found that the oxidation of GSH proceeds rather slowly with $[2]^{6+},{ }^{62]}$ or fairly rap- 


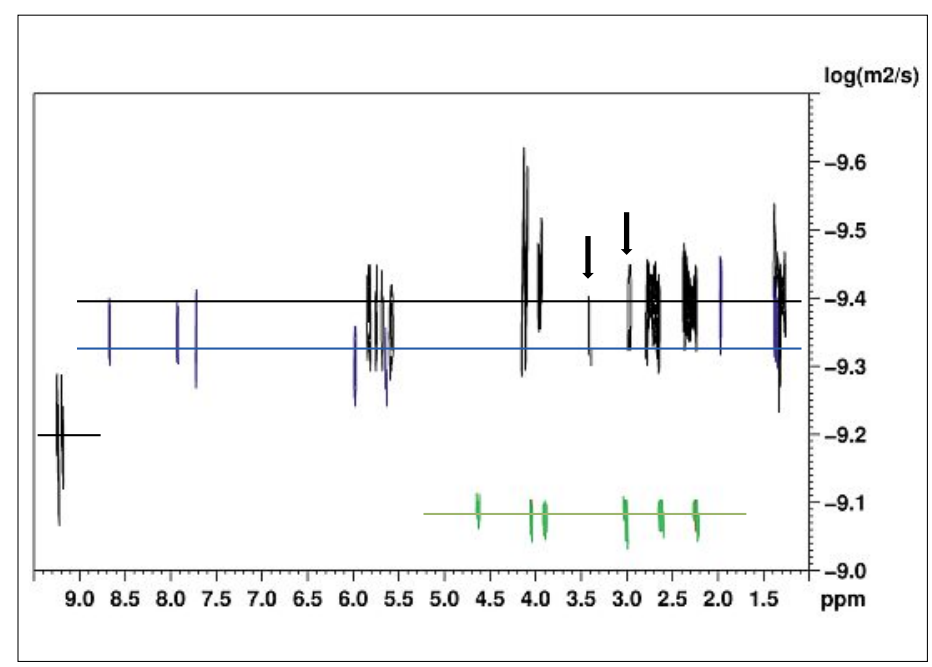

Fig. 11. 2D ${ }^{1} \mathrm{H}$ DOSY NMR spectrum of the solution containing $[1]^{6+}$ and GSH recorded in $\mathrm{D}_{2} \mathrm{O}$ at $37^{\circ} \mathrm{C}$ after $24 \mathrm{~h}$ (black), as well as superimposed 2D ${ }^{1} \mathrm{H}$ DOSY NMR spectra of $[1]^{6+}$ (blue) and free GSH (green) for comparison. The resonances of Cys in GSSG, which are indicated by arrows, clearly indicate that an adduct is formed upon the addition of GSSG to a water solution of $[1]^{6+}$

idly with $[\mathbf{1}]^{6+} .{ }^{[63]}$ In addition, the reaction of GSH with metallaprism $[\mathbf{1}]^{6+}$ reveals a rather unexpected result, since the DOSY spectrum of the mixture recorded after 24 $\mathrm{h}$ (Fig. 11) indicates that the metallaprism $[1]^{6+}$ loses both the tpt and the dhnq ligand and coordinated to the oxidized GSH, a characteristic not observed with the smaller metallaprism $[2]^{6+}$.

The oxidation observed for Cys and GSH in the presence of these metallaprisms suggest that a partial oxidation of free thiols present in blood plasma must be considered as a possible mechanism of action. The major thiol source in blood plasma is the protein human serum albumin (HSA), which is present at approximately $0.63 \mathrm{mM}$ concentration. This protein serves a number of important functions including the transport of drugs, metals, and hormones. Nevertheless, the only available thiol in HSA (Cys 34) is buried below the surface of the protein and hence is much less accessible than the thiol group in Cys and GSH. Yet, the results shown here suggest that these metallaprisms may interact with Cys 34 of HSA.

Our results strongly suggest that hexanuclear areneruthenium metallaprisms will preferentially react to amino groups, while simultaneously oxidizing ascorbic acid, Cys and GSH to dehydroascorbic acid, cystine and GSSG. Thus, serum proteins like serum albumin and transferrin are attractive targets for these and more generally for areneruthenium metalla-assemblies. The coordination mode of these prisms is distinct from the coordination chemistry of other cytotoxic Ru-complexes, and the results are consistent with other studies that do not necessarily implicate Ru-DNA adducts in the mechanism of action. ${ }^{[12]}$ Further studies to determine the coordination of nucleotides and DNA to areneruthenium metallaprisms will be useful in further establishing their mechanism of action. Our results provide evidence against interaction with proteins as process in the release of encapsulated guest molecules. Oxidation of Cys and GSH to give the corresponding disulphides may explain the higher in vitro anticancer activity of $[\mathbf{1}]^{6+}$ compared to $[2]^{6+}$.

\section{Conclusions}

In this article, we hope we could show that NMR spectroscopy has much to offer in the exciting fields of bioinorganic and bioorganometallic chemistry. NMR studies have played an important role in identifying possible metabolites and mechanisms for activation in vivo of cisplatin, in the clinic for more than 30 years. Advances in the design of metal complexes as drugs will benefit greatly from the detailed kinetic and thermodynamic information that NMR spectroscopy can provide under conditions of physiological relevance. From the spectroscopic point of view, very simple NMR experiments are most of the time appropriate for solving demanding structural problems such as mechanisms of action and cellular targets of inorganic drugs. In the light of the results presented in this study, we believe that two experiments are extremely useful: the first one is the 2D HSQC NMR spectroscopy. This experiment allows reactions of metal drugs to be studied in aqueous solutions at micromolar concentrations in complex biological media or in the presence of large biomolecules (proteins, DNA). The resulting chemical shifts often allow the intermediates and/or products to be readily identified, especially if combined with other analytical techniques such as HPLC and ESI-MS studies. The second experiment is 2D DOSY NMR spectroscopy, perhaps not so well known among scientists not directly implicated with NMR spectroscopy. This experiment provides useful insights about the nature of the intermediates and/ or products that are formed upon the addition of the drugs. ${ }^{[67-70]}$ The resulting dif- fusion coefficients often allow to readily identify whether a drug forms adducts or not with its presumed target(s).

For macromolecules (e.g. DNA and proteins) NMR offers the possibility of determining the three-dimensional structure of the macromolecule in solution and hence of characterizing drug-induced changes in macromolecule structure (which can in turn trigger biological effects). It is clear, however, that NMR does not always provide all the details of particular reactions, particularly because of limited sensibility and size limit.

\section{Acknowledgments}

We thank the Departement für Chemie und Biochemie of the University Berne and the Swiss National Foundation (Grant $N^{\circ}$ 200021131867) for financial support.

Received: July 17, 2012

[1] B. Rosenberg, L. V. Camp, E. B. Grimley, A. J. Thomson, J. Biol. Chem. 1967, 242, 1347.

[2] D. R. Feldman, G. J. Bosl, J. Sheinfeld, R. J. Motzer, J. Am. Med. Assoc. 2008, 299, 672.

[3] G. Sava, A. Bergamo, P. J. Dyson, Dalton Trans. 2006, 35, 1929.

[4] G. Sava, A. Bergamo, P. J. Dyson, Dalton Trans. 2011, 40, 9069.

[5] K. Lloyd, Nat. Rev. Canc. 2007, 7, 573.

[6] J. Yongwon, S. J. Lippard, Chem. Rev. 2007, 107, 1387.

[7] N. J. Wheate, S. Walker, G. E. Craig, R. Oun, Dalton Trans. 2010, 39, 8113

[8] F. P. Dwyer, E. C. Gyarfas, W. P. Rogers, J. H. Koch, Nature 1952, 170, 190.

[9] M. J. Clarke, Met. Ions Biol. Syst. 1980, 11, 231.

[10] G. Süss-Fink, Dalton Trans. 2010, 39, 1673

[11] G. Gasser, I. Ott, N. Metzler-Nolte, J. Med. Chem. 2011, 54, 3 .

[12] A. L. Noffke, A. Habtemariam, A. M. Pizarro, P. J. Sadler, Chem. Commun. 2012, 48, 5219

[13] A. Bergamo, G. Sava, Dalton Trans. 2011, 40, 7817.

[14] M. Groessl, C. G. Hartinger, K. Polec-Pawlak, M. Jarosz, P. J. Dyson, B. K. Keppler, Chem. Biodiversity 2008, 5, 1609

[15] J. M. Rademaker-Lakhai, D. B. D. Van, D. Pluim, J. H. Beijnen, J. H. M. Schellens, Clin. Cancer Res. 2004, 10, 3717.

[16] A. Bergamo, C. Gaiddon, J. H. M. Schellens, J. H. Beijnen, G. Sava, J. Inorg. Biochem. 2012, 106,90

[17] C. S. Allardyce, P. J. Dyson, D. J. Ellis, S. L. Heath, Chem. Commun. 2001, 1396.

[18] R. E. Morris, R. E. Aird, P. d. S. Murdoch, H. Chen, J. Cummings, N. D. Hughes, S. Pearsons, A. Parkin, G. Boyd, D. I. Jodrell, P. J. Sadler, J. Med. Chem. 2001, 44, 3616.

[19] R. E. Aird, J. Cummings, A. A. Ritchie, M. Muir, R. E. Morris, H. Chen, P. J. Sadler, D. I. Jodrell, Br. J. Cancer 2002, 86, 1652.

[20] E. Meggers, G. Ekin Atilla-Gokcumen, H. Bregman, J. Maksimoska, S. P. Mulcahy, N. Pagano, D. S. Williams, Synlett 2007, 8, 1177.

[21] K. S. M. Smalley, R. Contractor, N. K. Haass, A. N. Kulp, G. Ekin Atilla-Gokcumen, D. S Williams, H. Bregman, K. T. Flaherty, M. S. Soengas, E. Meggers, M. Herlyn, Cancer Res. 2007, 67, 209

[22] E. S. Antonarakis, A. Emadi, Cancer Chemother. Pharmacol. 2010, 66, 1.

[23] A. Bergamo, A. Masi, P. J. Dyson, G. Sava, Int. J. Oncol. 2008, 33, 1281. 
[24] B. Wu, M. S. Ong, M. Groessl, Z. Adhireskan, C. G. Hartinger, P. J. Dyson, C. A. Davey, Chem. Eur. J. 2011, 17, 3562.

[25] W. H. Ang, A. Casini, G. Sava, P. J. Dyson, J. Organomet. Chem. 2011, 696, 989.

[26] L. Ronconi, P. J. Sadler, Coord. Chem. Rev. 2008, 252, 2239.

[27] J. Vinje, E. Sletten, Anti. Canc. Agents Med. Chem. 2007, 7, 35.

[28] S. J. Berners-Price, L. Ronconi, P. J. Sadler, Prog. Nucl. Magn. Reson. Spectrosc. 2006, 49, 65.

[29] F. D. Rochon, A. L. Beauchamp, C. Dion, Inorg. Chim. Acta 2009, 362, 3885.

[30] C. I. Diakos, B. A. Messerle, P. del S. Murdoch, J. A. Parkinson, P. J. Sadler, R. R. Fenton, T. W. Hambley, Inorg. Chem. 2009, 48, 3047.

[31] C. Alvheim, N. A. Froystein, J. Vinje, F. P. Intini, G. Natile, Y. Liu, R. Huang, E. Sletten, Inorg. Chim. Acta 2009, 362, 907.

[32] E. Almaraz, Q. A. de Paula, Q. Liu, J. H. Reibenspies, M. Y. Darensbourg, N. P. Farrell, J. Am. Chem. Soc. 2008, 130, 6272.

[33] M. J. Clarke, F. Zhu, D. R. Frasca, Chem. Rev. 1999, 99, 2511.

[34] F. Wang, J. Xu, A. Habtemariam, P. J. Sadler, J. Am. Chem. Soc. 2005, 127, 17734.

[35] P. J. Dyson, G. Sava, Dalton Trans. 2006, 35, 1929.

[36] S. Chatterjee, S. Kundu, A. Bhattacharyya, C. G. Hartinger, P. J. Dyson, J. Biol. Inorg. Chem. 2008, 13, 1149.

[37] R. E. Morris, R. E. Aird, P. S. Murdoch, H. Chen, J. Cummings, N. D. Hughes, S. Parsons, A. Parkin, G. Boyd, D. I. Jodrell, P. J. Sadler, J. Med. Chem. 2001, 44, 3616.

[38] T. Burgarcic, A. Habtemariam, J. Stepankova, P. Heringova, J. Kasparkova, R. J. Deeth, R. D. L. Johnstone, A. Prescimone, A. Parkin, S. Parsons, V. Brabec, P. J. Sadler, Inorg. Chem. 2008, 47, 11470.
[39] H. Chao, Y.-X. Yuan, F. Zhou, L.-N. Ji, J. Zhang, Trans. Met. Chem. 2006, 31, 465.

[40] C. Rajput, R. Rutkaite, L. Swanson, I. Haq, J. A. Thomas, Chem. Eur. J. 2006, 12, 4611.

[41] C. S. Allardyce, P. J. Dyson, J. Cluster Sci. 2001, 12, 563 .

[42] C. S. Allardyce, P. J. Dyson, D. J. Ellis, P. A. Salter, R. Scopelliti, J. Organomet. Chem. 2003, $668,35$.

[43] B. Therrien, G. Süss-Fink, P. Govindaswamy, A. K. Renfrew, P. J. Dyson, Angew. Chem. Int. Ed. 2008, 47, 3773.

[44] N. P. E. Barry, N. H. Abd Karim, R. Vilar, B. Therrien, Dalton Trans. 2009, 38, 10717.

[45] F. Schmitt, P. Govindaswamy, G. Süss-Fink, W. H. Ang, P. J. Dyson, L. Juillerat-Jeanneret, B. Therrien, J. Med. Chem. 2008, 51, 1811.

[46] F. Schmitt, M. Auzias, P. Stepincka, Y. Sei, K. Yamagauchi, G. Süss-Fink, B. Therrien, L. Juillerat-Jeanneret, J. Biol. Inorg. Chem. 2009, 14, 693.

[47] F. Schmitt, P. Govindaswamy, O. Zava, G. SüssFink, L. Juillerat-Jeanneret, B. Therrien, J. Biol. Inorg. Chem. 2009, 14, 101.

[48] T. Gianferra, I. Bratsos, E. Alessio, Dalton Trans. 2009, 38, 7588.

[49] F. Chérioux, C. M. Thomas, T. Monnier, G. Süss-Fink, Polyhedron 2003, 22, 543.

[50] M. Gras, B. Therrien, G. Süss-Fink, O. Zava, P. J. Dyson, Dalton Trans. 2010, 39, 10305.

[51] F. Giannini, G. Süss-Fink, J. Furrer, Inorg. Chem. 2011, 50, 10552.

[52] D. Sharma, K. Rajarathnam, J. Biomol. NMR 2000, 18, 165 .

[53] S. J. Dougan, A. Habtemariam, S. E. McHale, S. Parsons, P. J. Sadler, Proc. Natl. Acad. Sci. USA 2008, 105, 11628 .
[54] F. Giannini, J. Furrer, A.-F. Ibao, G. Süss-Fink, B. Therrien, M. Baquie, O. Zava, P. J. Dyson, P. Štěpnička, J. Biol. Inorg. Chem. 2012, 6, 951.

[55] Y. Matsumura, H. Maeda, Cancer. Res. 1986, $46,6387$.

[56] B. Therrien, Eur. J. Inorg. Chem. 2009, 2445.

[57] V. Vajpayee, Y. J. Yang, S. C. Kang, H. Kim, I. S. Kim, M. Wang, P. J. Stang, K. W. Chi, Chem. Commun. 2011, 47, 5184.

[58] B. Therrien, G. Süss-Fink, P. Govindaswamy, A. K. Renfrew, P. J. Dyson, Angew. Chem., Int. Ed. 2008, 47, 3773 .

[59] B. P. Esposito, R. Najjar, Coord. Chem. Rev. 2002, 232, 137.

[60] M. I. Weeb, C. J. Walsby, Dalton Trans. 2011, 40, 1322.

[61] W. Hu, Q. Luo, K. Wu, X. Li, F. Wang, Y. Chen, X. Ma, J. Wang, J. Liu, S. Xiong, P. J. Sadler, Chem. Commun. 2011, 47, 6006.

[62] L. E. H. Paul, B. Therrien, J. Furrer, Inorg. Chem. 2012, 51, 1057.

[63] L. E. H. Paul, B. Therrien, J. Furrer, J. Biol. Inorg. Chem. 2012, 7, 1053.

[64] F. Wang, H. Chen, J. A. Parkinson, P. d. S. Murdoch, P. J. Sadler, Inorg. Chem. 2002, 41, 4509.

[65] M. Hanif, H. Henke, S. M. Meier, S. Martic, M. Labib, W. Kandioller, M. A. Jakupec, V. B. Arion, H.-B. Kraatz, B. K. Keppler, C. G. Hartinger, Inorg. Chem. 2010, 49, 7953.

[66] S. M. Meier, M. Hanif, W. Kandioller, B. K. Keppler, C. G. Hartinger, J. Inorg. Biochem. 2012, 108, 91.

[67] K. F. Morris, C. S. Johnson, J. Am. Chem. Soc. 1993, 115, 4291.

[68] H. Barjat, G. A. Morris, S. Smart, A. G. Swanson, S. C. R. Williams, J. Magn. Reson. B 1995, 108, 170

[69] M. D. Pelta, H. Barjat, G. A. Morris, A. L. Davis, S. J. Hammond, Magn. Reson. Chem. 1998, 36, 706.

[70] B. Antalek, Conc. Magn. Reson. 2002, 14, 225. 